University of Nebraska - Lincoln

DigitalCommons@University of Nebraska - Lincoln

2009

\title{
Nutrient Uptake and Mineralization during Leaf Decay in Streams - A Model Simulation
}

J. R. Webster

Virginia Polytechnic Institute and State University, jwebster@vt.edu

J. D. Newbold

Stroud Water Research Center, Avondale, PA

Steven A. Thomas

University of Nebraska - Lincoln, sthomas5@unl.edu

P. J. Mulholland

Oak Ridge National Laboratory

Follow this and additional works at: https://digitalcommons.unl.edu/natrespapers

Part of the Natural Resources and Conservation Commons

Webster, J. R.; Newbold, J. D.; Thomas, Steven A.; and Mulholland, P. J., "Nutrient Uptake and Mineralization during Leaf Decay in Streams - A Model Simulation" (2009). Papers in Natural Resources. 172.

https://digitalcommons.unl.edu/natrespapers/172

This Article is brought to you for free and open access by the Natural Resources, School of at DigitalCommons@University of Nebraska - Lincoln. It has been accepted for inclusion in Papers in Natural Resources by an authorized administrator of DigitalCommons@University of Nebraska - Lincoln. 


\title{
DOI: 10.1002/iroh.200811158
}

\author{
J. R. Webster ${ }^{*}, 1$, J. D. Newbold ${ }^{2}$, S. A. Thomas ${ }^{3}$, H. M. Valett ${ }^{1}$ and P. J. Mulholland ${ }^{4}$ \\ ${ }^{1}$ Department of Biological Sciences, Virginia Polytechnic Institute and State University, \\ Blacksburg, Virginia, 24061, USA; e-mail: jwebster@vt.edu \\ ${ }^{2}$ Stroud Water Research Center, 970 Spencer Road, Avondale, Pennsylvania, 19311, USA \\ ${ }^{3}$ School of Natural Resources, University of Nebraska, Lincoln, Nebraska, 68583, USA \\ ${ }^{4}$ Environmental Sciences Division, Oak Ridge National Laboratory, \\ P.O. Box 2008, Oak Ridge, Tennessee, 37831, USA
}

\section{Research Paper \\ Nutrient Uptake and Mineralization during Leaf Decay in Streams - a Model Simulation}

key words: nitrogen, phosphorus, leaf breakdown, model, stoichiometry

\begin{abstract}
We developed a stoichiometrically explicit computer model to examine how heterotrophic uptake of nutrients and microbial mineralization occurring during the decay of leaves in streams may be important in modifying nutrient concentrations. The simulations showed that microbial uptake can substantially decrease stream nutrient concentrations during the initial phases of decomposition, while mineralization may produce increases in concentrations during later stages of decomposition. The simulations also showed that initial nutrient content of the leaves can affect the stream nutrient concentration dynamics and determine whether nitrogen or phosphorus is the limiting nutrient. Finally, the simulations suggest a net retention (uptake $>$ mineralization) of nutrients in headwater streams, which is balanced by export of particulate organic nutrients to downstream reaches. Published studies support the conclusion that uptake can substantially change stream nutrient concentrations. On the other hand, there is little published evidence that mineralization also affects nutrient concentrations. Also, there is little information on direct microbial utilization of nutrients contained in the decaying leaves themselves. Our results suggest several directions for research that will improve our understanding of the complex relationship between leaf decay and nutrient dynamics in streams.
\end{abstract}

\section{Introduction}

HYNES (1960) illustrated changes in dissolved nutrient concentrations downstream of a sewage outfall, noting first the initial increases due to mineralization of organic sewage and then the subsequent downstream decreases as nutrients were immobilized by autotrophic processes. A later paper by KAUSHIK and HYNES (1971) demonstrated another important process: heterotrophic uptake (or immobilization) of nitrogen by microbes associated with decaying leaves. Hence, microbial processing of allochthonous organic material may liberate or sequester nutrients depending on characteristics of the microbes and their resources. We developed a stoichiometrically explicit computer model to examine two of these processes that occur during the decay of leaves in freshwater streams - heterotrophic uptake of

\footnotetext{
* Corresponding author
} 
nutrients and subsequent mineralization. Our primary objective was to examine the importance of these processes in regulating nutrient concentrations in streams where inorganic nitrogen and phosphorus availability may limit biological processes and where allochthonous import of autumnal leaves is a critical part of the energetics of the stream.

The concept of ecological stoichiometry (STERNER and ELSER, 2002) addresses how the elemental composition of producers, consumers, and their interactions drive changes in nitrogen and phosphorus availability and alter nutrient limitation of biotic processes. Generally, studies of consumer-driven nutrient cycling have been applied to relatively closed ecosystems (e.g., lakes) or grazing-based food webs within streams (e.g., STELZER and LAMBERTI, 2002; FROST et al., 2002) without emphasis on transport. Also, ecological stoichiometry has been most widely applied to systems where autochthonous processes and primary producers dominate and allochthonous inputs and detrital stores are less important (e.g., Frost et al., 2002). However, detrital nutrient content can control heterotrophic activity and carbon accumulation within ecosystems (e.g., CEBRIÁN et al., 1998). Recent theoretical work has addressed how ecological stoichiometry concepts may be applied to open and detritus-based ecosystems and their processes (e.g., streams; CROSs et al., 2005; SCHADE et al., 2005). Unidirectional transport renders streams unique systems in which to assess relationships between nutrient supply, organismal stoichiometry, and biotic influences on downstream ecosystems.

The composition and functional characteristics of microbial associations with detritus and inorganic surfaces dictate the manner by which biogeochemical cycling of nitrogen and phosphorus are coupled in streams. Accordingly, the intensity of linkage between uptake from the water column and organism stoichiometry should depend on (1) the extent to which microbes rely on particulate or dissolved resources, and (2) how flexible these organisms are in regards to their elemental composition. Microbial nutrient uptake may be either homeostatic and consistently reflect biomass composition or non-homeostatic (i.e., plastic), allowing for luxury uptake and varying demand relative to existing biomass stoichiometry. Results from previous studies suggest that autotrophic biofilms are stoichiometrically plastic since biomass $\mathrm{N}$ : P for a given biofilm composition can vary with environmental conditions (Francoeur, 2001; TANK and Dodds, 2003; Dodds et al., 2004) while elemental composition of heterotrophic bacteria and fungi are more homeostatic (STERNER and ELSER, 2002; MAKINO et al., 2003). However, a few studies have observed limited elemental plasticity of aquatic bacteria (e.g., TezUKA, 1990; ChrZANOWSKI and Kyle, 1996), and there is some evidence that fungi respond to low phosphorus by storing phosphorus in polyphosphate granules, reducing the phosphorus content of cell walls, and partially replacing phospholipid with phosphorus-free lipid (BEEVER and BuRns, 1980; JENNINGS, 1995).

Investigations of nutrient dynamics in streams have almost exclusively focused on uptake processes, while quantitative information on mineralization has been limited to whole-stream tracer studies (e.g., NewBold et al., 1983; Peterson et al., 2001) or estimates of nutrient regeneration rates by animal excretion (e.g. WANNI, 2002; HoOD et al., 2005; McInTYRE et al., 2008). As a result, there is little understanding of how instream nutrient processes influence the absolute and relative availability of nitrogen and phosphorus and ultimately influence the structure and function of downstream systems. Our objective was to determine how heterotrophic uptake of nutrients and microbial mineralization occurring during the decay of leaves in freshwater may be important in modifying nutrient concentrations in streams.

\section{Model Description}

Our approach to assessing nutrient uptake and mineralization associated with leaf decay was to construct a computer model based on our current understanding of these processes. The model (Fig. 1) has four components - inorganic nutrients in solution in the water col- 


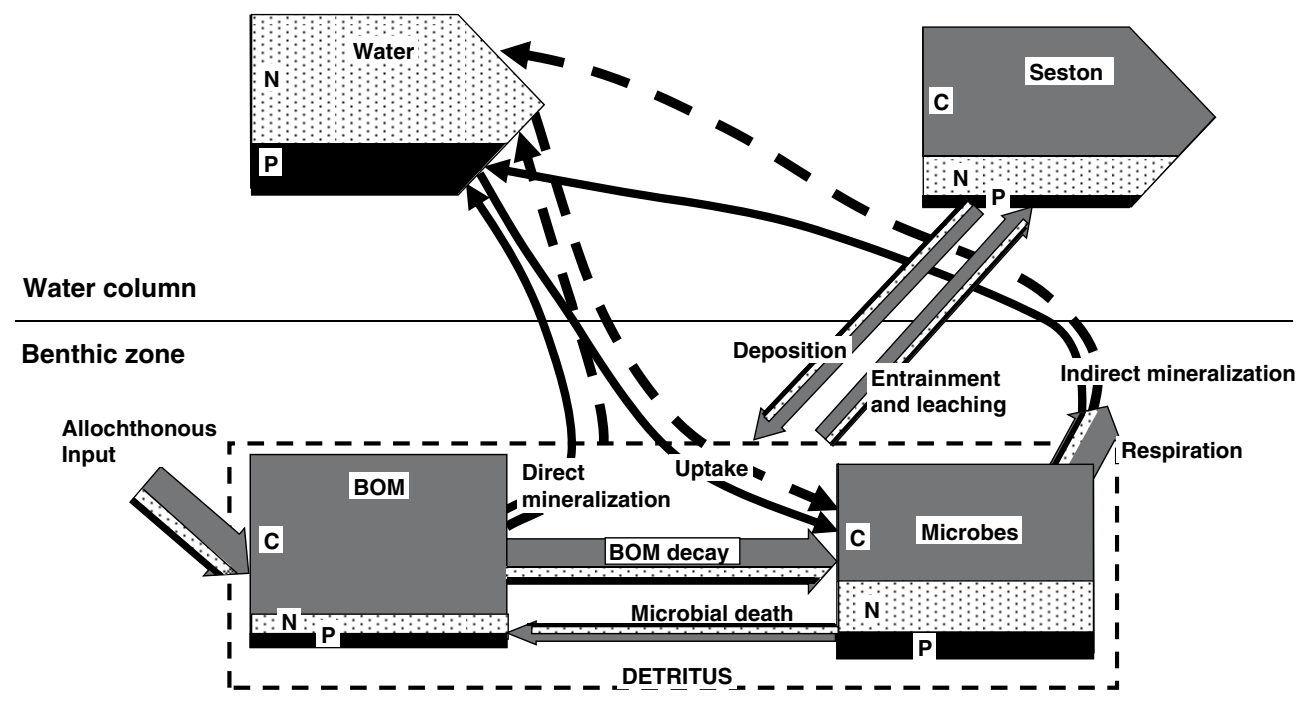

Figure 1. Model of nutrient and carbon dynamics in a stream dominated by allochthonous organic sources. Water and seston compartments are in transport in the water column. Detritus, made up of decaying leaves (BOM) and associated microbes, is stationary on the stream bottom. Solid and dashed arrows represent flows of inorganic phosphorus and nitrogen. Other arrows represent flows of organic materials including organic carbon, nitrogen, and phosphorus. Within these arrows and within the compartments, gray shading represents carbon, black is phosphorus, and dotted areas are nitrogen, though these fractions are not represented in realistic stoichiometric ratios.

umn, seston (particles in transport in the water column - in this model we consider only the organic portion of transported particles), decaying leaves on the stream bottom (benthic organic matter, BOM), and the microbes associated with these decaying leaves. In parameterizing the model, we used data for nitrogen and phosphorus, where the inorganic forms of these nutrients are soluble reactive phosphorus and total inorganic nitrogen (= nitrate, nitrite, and ammonium). The microbes responsible for leaf decay are both fungi and bacteria, but the parameters of our model are based primarily on fungi, assuming that they are the primary agents of leaf decay in freshwater streams, at least during the earlier stages of leaf decay (e.g., SuBERKROPP and KLUG, 1976). The model is 'stoichiometrically explicit' in that state variables exist for the standing stocks of nitrogen, phosphorus, and organic carbon within each compartment (except there is no carbon in the water compartment) and transfers among compartments are mechanistically constrained by ratios of elemental abundance and distribution. Our conceptualization of the fluxes among the model compartments is based on ten basic simplifications. The validity of some of these simplifications is considered in the discussion.

1. Microbial assimilation of organic material is equal to BOM decay - that is, the decay process involves the transfer of organic carbon and associated nitrogen and phosphorus from decaying leaves to microbes. The assimilated organic carbon can then be used for microbial growth and respiration. Thus we are considering only one aspect of leaf breakdown, and our model does not include breakage, leaching of organic compounds, or invertebrate consumption.

2. The microbes responsible for BOM decay have a fixed $\mathrm{C}: \mathrm{N}: \mathrm{P}$ requirement - that is, they have no stoichiometric plasticity. 
3. The nutrients (N and $\mathrm{P}$ ) for microbial assimilation can come from either the organic substrate (BOM) or from the water column, but if available they are taken from the substrate first. Uptake from the water column only occurs as needed.

4. If nitrogen and phosphorus are in excess in the substrate, microbial assimilation of carbon (and leaf decay) occurs at the maximum rate.

5. If either nitrogen or phosphorus is insufficient in the substrate, microbial assimilation is limited by the nitrogen or phosphorus available from the water according to Monod kinetics.

6. Direct mineralization of nutrients occurs when the nutrient supply in the BOM is greater than the needs of the microbes, i.e., when the $\mathrm{C}: \mathrm{P}$ or $\mathrm{C}: \mathrm{N}$ of the $\mathrm{BOM}$ is less than the $\mathrm{C}: \mathrm{P}$ or $\mathrm{C}: \mathrm{N}$ requirement of the microbes. The excess nutrient is released into the water column.

7. Indirect mineralization occurs as the microbes associated with the leaves respire. As they metabolize organic carbon into $\mathrm{CO}_{2}$, the associated nitrogen and phosphorus are released into the water column in inorganic form. Respiration by microbes associated with seston was included in the computer code, but it was set to zero in the simulations described in this paper based on the very low rates of respiration reported for seston in heterotrophic streams (e.g., PETERS et al., 1987).

8. Entrainment of BOM and microbes are linked, that is, microbes are part of the detritus and they are transported together. Similarly, deposition of seston includes both dead organic particles and associated microbes. Both entrainment and deposition include organic carbon, nitrogen, and phosphorus in ratios of their respective source compartments.

9. Microbial death returns organic carbon, nitrogen, and phosphorus to BOM according to the elemental ratios of the microbes.

10. Allochthonous input brings organic carbon, nitrogen, and phosphorus into the stream in a fixed ratio determined by the plant species composition of the litterfall.

Model quantification was based on studies of Hugh White Creek (Coweeta Hydrologic Laboratory, North Carolina, USA) and other streams in that area. Nominal parameter values and initial conditions (Table 1) were derived from past research or assigned to achieve realistic initial simulations. Our simulations were based on a $1000-\mathrm{m}$ stream reach with a $1-\mathrm{m}$ wide and $20-\mathrm{cm}$ deep channel and a discharge of $20 \mathrm{~L} / \mathrm{s}$. We used the model to simulate a 90-day response following a pulse input of unconditioned leaves.

The model was programmed as $10001-\mathrm{m}$ stream segments. Within each segment, all 11 state variables were dynamically updated using the Runge-Kutta integration technique every $10 \mathrm{~s}$. After each dynamic integration step, water column variables were moved downstream one segment $(10 \mathrm{~s} \times \mathrm{Q} /(\mathrm{w} \times \mathrm{d})=1 \mathrm{~m})$, and the upstream water column segment was reset to initial values. Most of the results we present are based on the conditions at the downstream end of the reach over the 90-day simulation. For a longer simulation time or a shorter simulation distance, we would see depletion of BOM due to transport. For example after 75 days, BOM was almost completely absent from the upper $400 \mathrm{~m}$ of stream, and after about 110 days BOM began to be depleted from the downstream end of the reach reflecting the influence of transport processes. We do include some results for cumulative export after 190 days, when essentially all material was gone from the reach. The model was programmed in $\mathrm{C}^{++}$and executed using ABSOFT software (ABSOFT Corporation, Rochester Hills, Michigan, USA) with a DISLIN user interface (DISLIN Scientific Plotting Software, Max Planck Institute for Solar System Research, Lindau, Germany).

In this paper we present the results of two simulations. In the first simulation, we used the parameter values shown in Table 1 with low-nutrient leaves typical of mixed litter of deciduous forests. In the second, we increased the nitrogen content of the leaves from 1.2 to $2.1 \%$ generating a $\mathrm{C}: \mathrm{N}$ of 24 (all elemental ratios in this paper are reported as mass 
Table 1. Nominal parameters and initial conditions used in the simulations. $\mathrm{C}: \mathrm{P}$ and $\mathrm{C}: \mathrm{N}$ are mass ratios.

\begin{tabular}{|c|c|c|}
\hline Parameter & Value & Source \\
\hline Maximum leaf decay rate & $0.03 \mathrm{~d}^{-1}$ & $\begin{array}{l}\text { Three times the average leaf breakdown rate } \\
\text { reported by WEBSTER et al. }\left(1999,0.0098 \mathrm{~d}^{-1}\right) \\
\text { based on results of GULIS and SUBERKROPP } \\
\text { (2003) for a nutrient amended stream }\end{array}$ \\
\hline Microbial respiration rate & $3.5 \times 10^{-7} \mathrm{~s}^{-1}$ & $\begin{array}{l}\text { Calculated from Gulis and SubERKROPP (2003) } \\
\text { for maple leaves in an unamended stream }\end{array}$ \\
\hline Microbial C:P & 250 & $\begin{array}{l}\text { BeEver and Burns (1980), Cromack and } \\
\text { CALDWELl (1992), Sterner and Elser } \\
\text { (2002), WALlander et al. (2002), OlsSON } \\
\text { et al. (2008) }\end{array}$ \\
\hline Microbial $\mathrm{C}: \mathrm{N}$ & 18 & $\begin{array}{l}\text { Newell and StATZELL-TAlLman (1982), } \\
\text { CromaCK and CAlDWELl (1992), SANZONE } \\
\text { et al. (2001), FindLay et al. (2002), } \\
\text { STERNER and ElSER (2002), Gulis et al. } \\
\text { (2006) }\end{array}$ \\
\hline $\begin{array}{l}\text { Half saturation constant }\left(\mathrm{k}_{\mathrm{s}}\right) \\
\text { for phosphorus }\end{array}$ & $1.0 \mathrm{mgP} / \mathrm{m}^{3}$ & $\begin{array}{l}\text { Determined to achieve realistic stream concen- } \\
\text { trations under nominal conditions }\end{array}$ \\
\hline $\begin{array}{l}\text { Half saturation constant }\left(\mathrm{k}_{\mathrm{s}}\right) \\
\quad \text { for nitrogen }\end{array}$ & $6.0 \mathrm{mgN} / \mathrm{m}^{3}$ & TANK et al. (2000), PAYN et al. (2005) \\
\hline Leaf fall & 0 & $\begin{array}{l}\text { The simulations begin just after autumn leaf } \\
\text { fall }\end{array}$ \\
\hline Leaf $\mathrm{C}: \mathrm{P}$ & 375 & $\begin{array}{l}\text { Average reported by STERNER and ELSER } \\
\text { (2002) }\end{array}$ \\
\hline Leaf $\mathrm{C}: \mathrm{N}$ & 31 & $\begin{array}{l}\text { Average reported by STERNER and ELSER } \\
(2002)\end{array}$ \\
\hline Seston deposition velocity & $0.00223 \mathrm{~m} / \mathrm{s}$ & WeBster et al. (1999) \\
\hline BOM entrainment coefficient & $1.0 \times 10^{-5} \mathrm{~s}^{-1}$ & $\begin{array}{l}\text { Set to balance deposition under nominal } \\
\text { conditions }\end{array}$ \\
\hline Microbial death rate & $1.0 \times 10^{-6} \mathrm{~s}^{-1}$ & $\begin{array}{l}\text { Set to achieve a balance between living and } \\
\text { dead microbes }\end{array}$ \\
\hline Initial $\mathrm{P}$ concentration in water ${ }^{1}$ & $2.0 \mathrm{mgP} / \mathrm{m}^{3}$ & Typical value for Coweeta streams \\
\hline Initial $\mathrm{N}$ concentration in water ${ }^{1}$ & $25.0 \mathrm{mgN} / \mathrm{m}^{3}$ & Typical value for Coweeta streams \\
\hline Initial BOM C & $216 \mathrm{gC} / \mathrm{m}^{2}$ & GOLLADAY et al. (1989), WEBSTER et al. (1999) \\
\hline Initial BOM P & $576 \mathrm{mgP} / \mathrm{m}^{2}$ & Based on leaf $\mathrm{C}: \mathrm{P}$ \\
\hline Initial BOM N & $6967 \mathrm{mgN} / \mathrm{m}^{2}$ & Based on leaf $\mathrm{C}: \mathrm{N}$ \\
\hline Initial microbial $\mathrm{C}, \mathrm{N}$, and $\mathrm{P}$ & 0 & $\begin{array}{l}\text { No microbes on the leaves at beginning of } \\
\text { simulations }\end{array}$ \\
\hline Initial seston $\mathrm{C}, \mathrm{N}$, and $\mathrm{P}^{1}$ & 0 & Seston is generated from BOM entrainment \\
\hline
\end{tabular}

\footnotetext{
${ }^{1}$ These values also represent upstream inputs.
} 
ratios). This would be typical of leaves of trees with $\mathrm{N}$-fixing symbionts such as alder (e.g., Chauvet, 1987).

\section{Results}

\subsection{Simulation 1, Low Nutrient Leaves}

In the first simulation, leaves lost $81 \%$ of their mass in 90 days (Fig. 2, left panels), but much of the leaf carbon had been transferred to microbial biomass. The actual detrital decay, i.e., including leaves and living and dead microbes, was only $32 \%$. After a period of microbial colonization, detrital decay was constant at about $0.02 \mathrm{~d}^{-1}$, about two-thirds of the maximum value. With the values used in the first simulation, leaves did not supply sufficient nutrients for maximum leaf decay - the $C: N$ and $C: P$ of the leaves was greater than the respective ratios needed by the microbes. Leaf decay was limited by the availability of inorganic nitrogen in the water column because water column N:P (initially 12.5) was less than the N:P needed by the microbes (13.9) throughout the simulation (Fig. 3). The actual rate of detrital disappearance, calculated from the slope of the line in Figure 2, upper left panel, was much slower than leaf decay $\left(\mathrm{k}=0.005 \mathrm{~d}^{-1}\right)$ because of the deposition of material

Simulation 1, low nutrient leaves

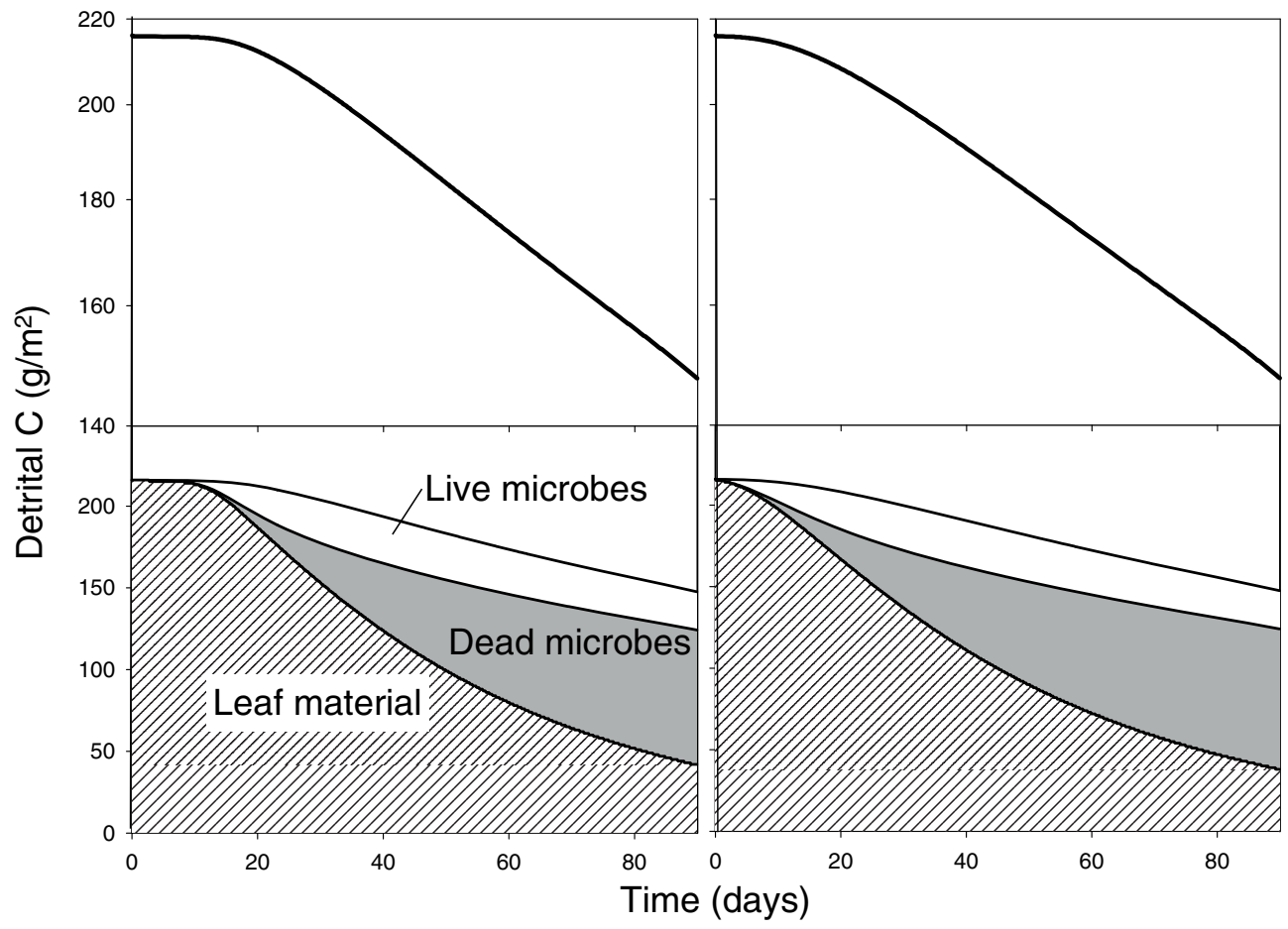

Figure 2. Detrital carbon in decomposing leaves for simulations with low nutrient leaves (Simulation 1, left panels) and high nitrogen leaves (Simulation 2, right panels). The vertical axes in the upper panels are logarithmic. 


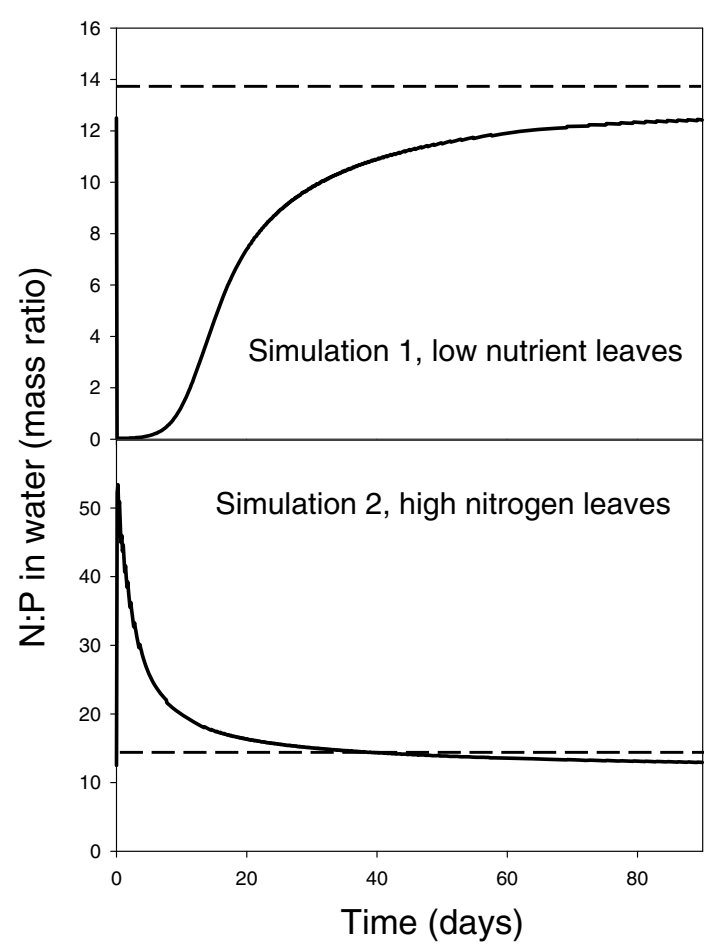

Figure 3. N : P mass ratios in water in the Simulation 1 (upper panel) and Simulation 2 (lower panel). The dashed lines represent the upstream and initial water $\mathrm{N}: \mathrm{P}$ ratios.

entrained from upstream. For sites further upstream, detrital disappearance was much faster because of transport downstream.

Microbial conditioning of leaves required about two weeks as indicated by the delay in decay and accrual of microbial biomass (Fig. 2, lower left panel). After 90 days, living microbes made up $17 \%$ of the detrital carbon. Microbial uptake of nitrogen and phosphorus resulted in accumulation of both elements (Fig. 4, left panels), but the increase in standing crop of these elements was somewhat less than the large increases seen in some stream experiments (e.g., TRISKA and BUCKLEY, 1978). After conditioning, live microbial nitrogen and phosphorus accounted for a maximum of 18 and $20 \%$ respectively of detrital nutrient stocks. After 90 days there was a slight net loss of phosphorus and a slight net gain of nitrogen (Fig. 4, left panels). Since carbon was decreasing over this time, detrital C:N and $\mathrm{C}: \mathrm{P}$ declined substantially (Fig. 5, left panels). This was due to the accumulation of the relatively nutrient-rich dead microbial material in the detritus (Figs. 2 and 4, left panels). After 90 days, dead microbial material accounted for $56 \%$ of the detrital carbon, $63 \%$ of the detrital nitrogen, and $61 \%$ of the detrital phosphorus.

Nutrient uptake (i.e., immobilization of nitrogen and phosphorus from the water column) increased rapidly after the initial period of microbial conditioning (Fig. 6, left panels). Uptake peaked after 18 days and then declined. Nutrient mineralization peaked somewhat later than uptake (day 43) and then declined more slowly (Fig. 7, left panels). As a result of these processes, net retention (i.e., uptake minus mineralization) was initially positive, 


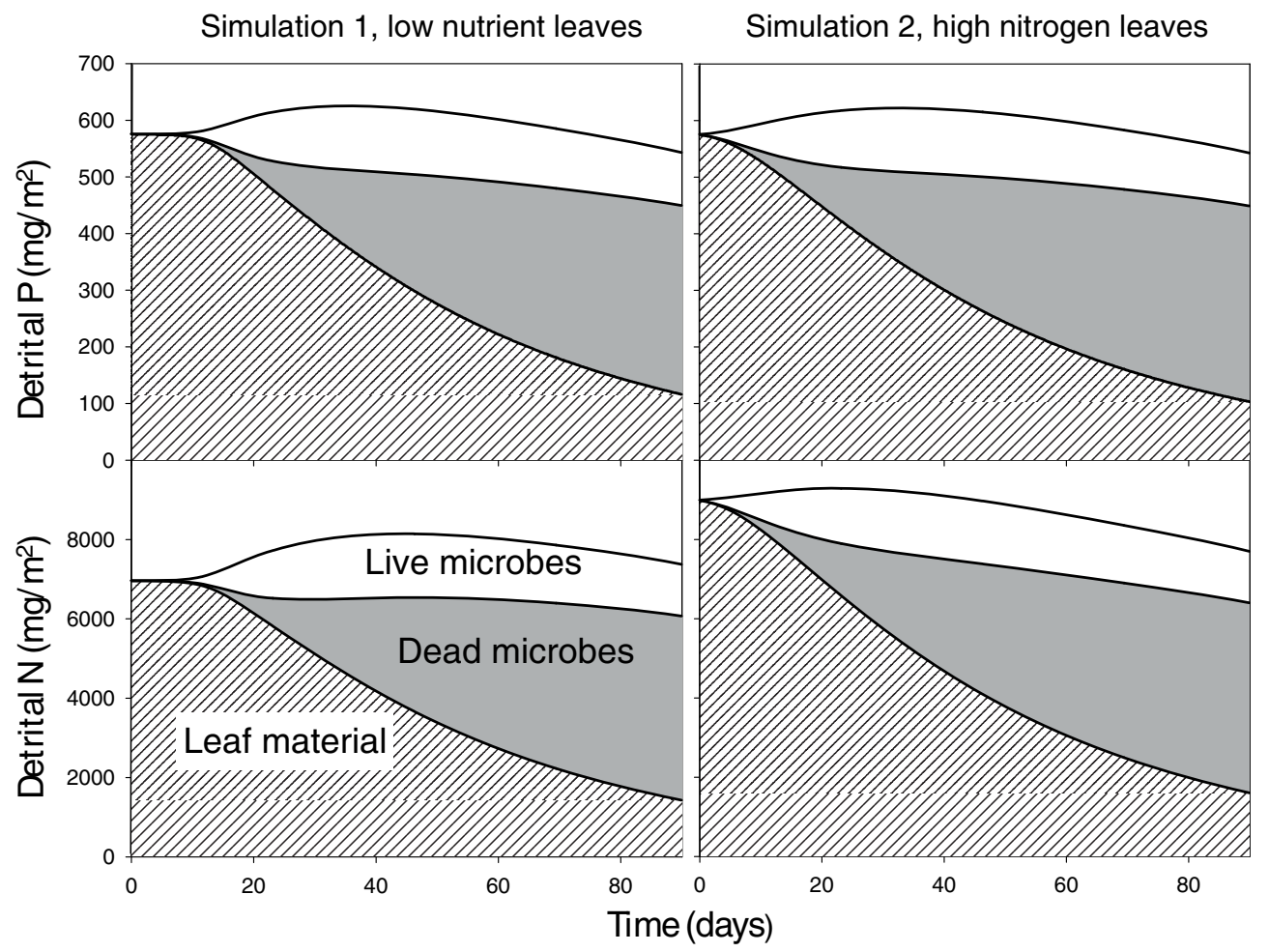

Figure 4. Phosphorus (upper panels) and nitrogen (lower panels) in decomposing leaves for simulations with low nutrient leaves (Simulation 1, left panels) and high nitrogen leaves (Simulation 2, right panels).

peaking about 17 days after the start of the simulation (Fig. 8, left panels). Net phosphorus retention became negative (mineralization exceeded uptake) after 36 days, while net nitrogen retention was positive for 45 days. Both phosphorus and nitrogen net retention remained negative (i.e., net mineralization) for the remainder of the decay period.

Net retention of nutrients greatly changed water column concentrations (Fig. 9, left panels). For the parameters used in these simulations, including low nutrients in the leaves, $\mathrm{N}: \mathrm{P}$ in water $=12.5$, and $\mathrm{N}: \mathrm{P}$ of microbes $=13.9$, nitrogen was the limiting nutrient, and accordingly nitrogen was reduced to very low levels (down to less than $0.1 \mu \mathrm{gN} / \mathrm{L}$ ) during the initial period of net nutrient retention. Phosphorus concentration was also reduced during this period but by only about $75 \%$. Once net retention became negative (Fig. 8, left panels), water column nutrient concentrations were increased above background levels.

Because there initially was net retention of both phosphorus and nitrogen, the cumulative transport of inorganic nutrients started out below what transport would have been with no uptake or mineralization (Fig. 10). By the time all leaf material had either decayed or been transported out of the reach (190 days, Table 2), export of dissolved inorganic phosphorus was only slightly greater than with no uptake or mineralization and particulate export was slightly smaller than with no uptake or mineralization. During the 190 days, there was a small net mineralization of leaf phosphorus. In contrast, there was net retention of inorganic 
Simulation 1, low nutrient leaves

Simulation 2, high nitrogen leaves

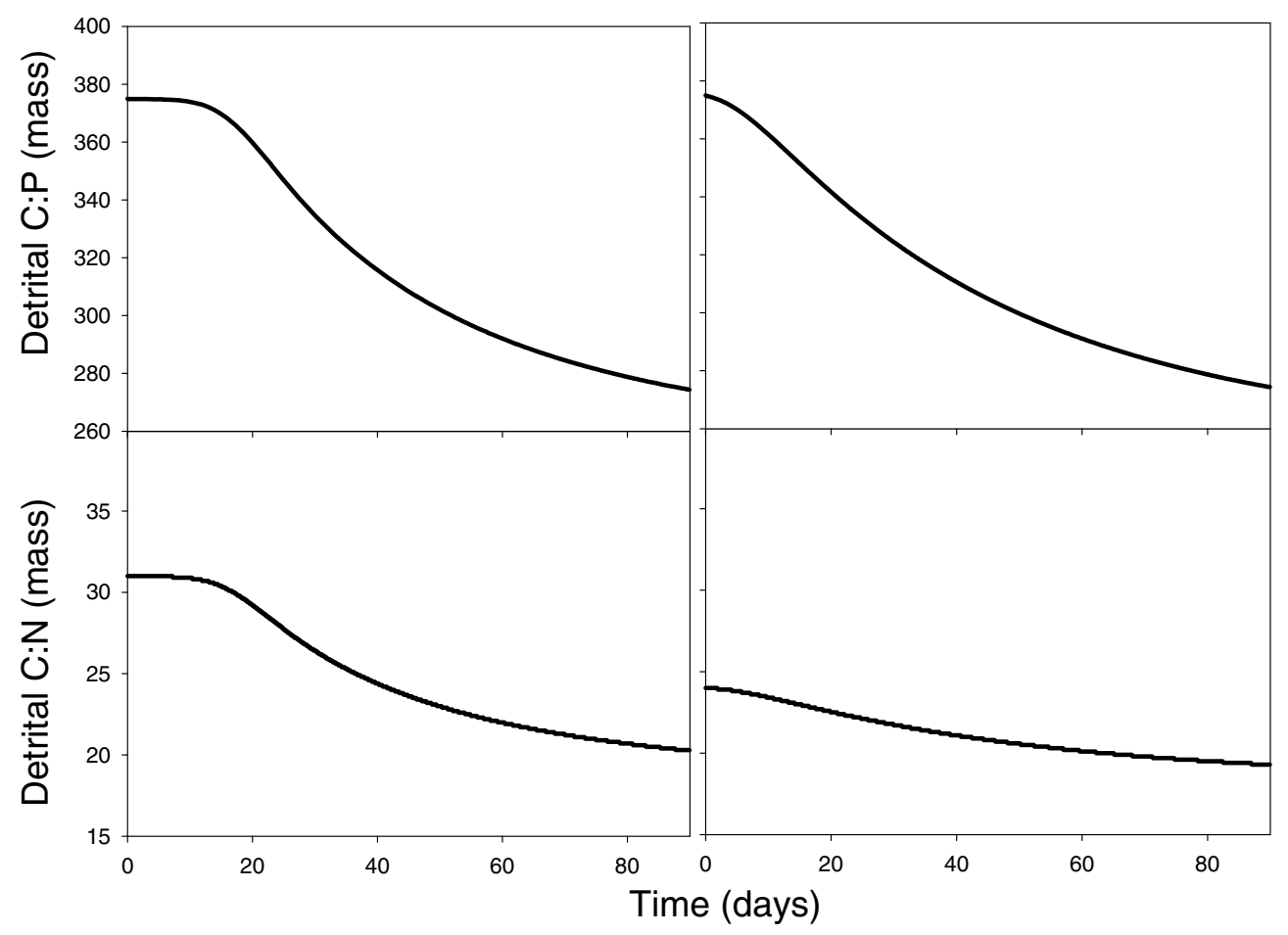

Figure 5. $\mathrm{C}: \mathrm{P}$ (upper panels) and $\mathrm{C}: \mathrm{N}$ (lower panels) ratios (mass) in decomposing leaves for simulations with low nutrient leaves (Simulation 1, left panels) and high nitrogen leaves (Simulation 2, right panels).

nitrogen (Fig. 10, lower panel, Table 2). Approximately $8 \%$ of the inorganic nitrogen entering the stream was immobilized and transported out as particulate organic nitrogen. During this same period, $21 \%$ of the leaf carbon was respired (Table 2).

\subsection{Simulation 2, High Nitrogen Leaves}

When we ran simulations using leaves with high nitrogen content $(\mathrm{C}: \mathrm{N}$ leaves $=24)$, there was little effect on leaf decay (Fig. 2) or phosphorus processes (Figs. 4-8, upper panels) as compared to Simulation 1; however, nitrogen processes were greatly affected. The biggest difference was the much shorter delay for microbial conditioning (Fig. 2). Because there was more nitrogen in the leaves, there was less demand for water column nitrogen, and water column nitrogen remained high enough to support microbial growth (Fig. 3). With the high nitrogen content of the leaves, living and dead microbes initially made up a smaller proportion of detrital nitrogen, but by the end of the 90-day simulation the proportions were very similar to the results from the low-nitrogen leaf simulation (Fig. 4, lower panels), but there was slightly more total detrital nitrogen remaining than in Simulation 1. With more nitrogen in the leaves, less demand from the water, and higher water column 


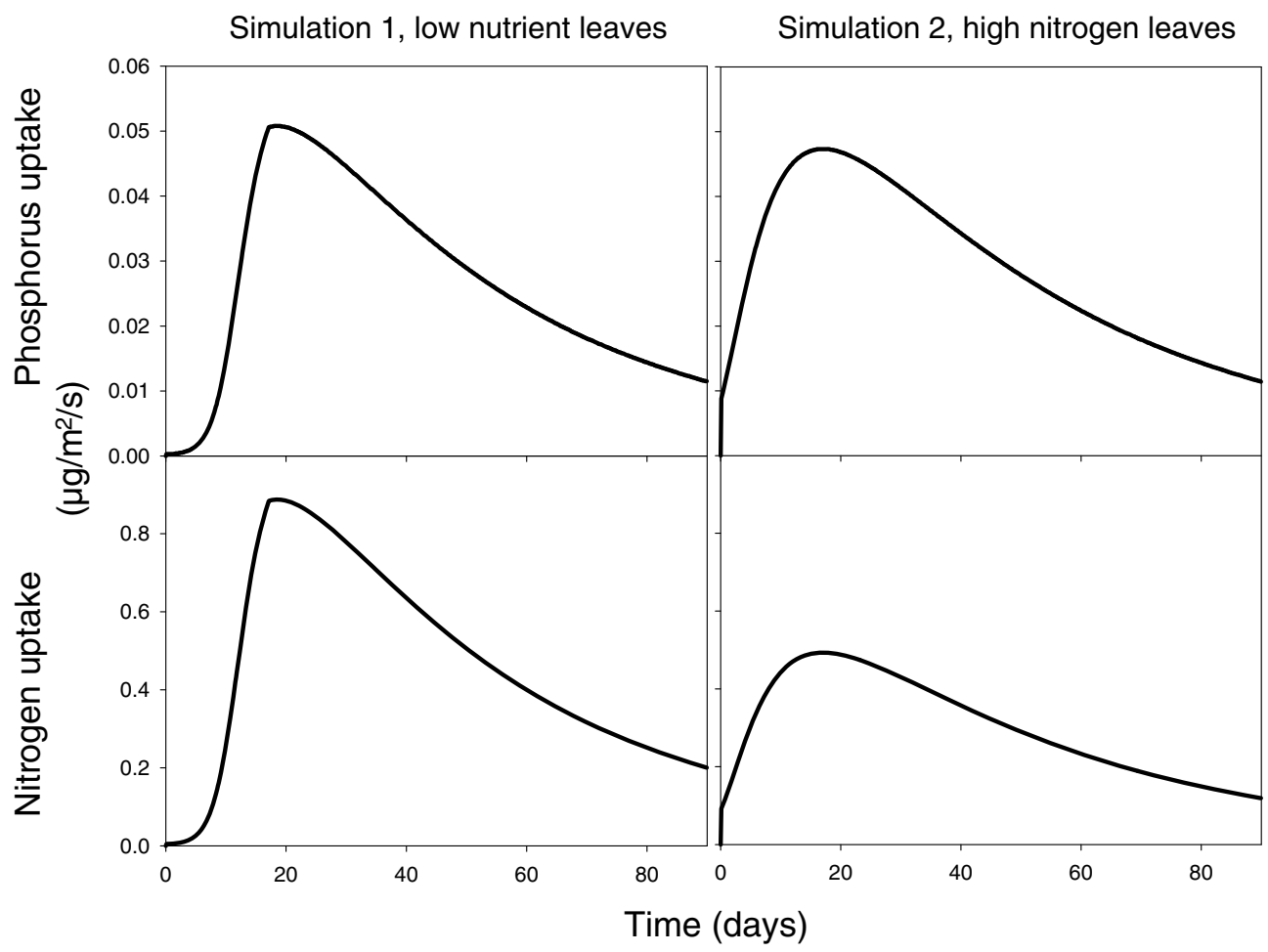

Figure 6. Phosphorus (upper panels) and nitrogen (lower panels) uptake in decomposing leaves for simulations with low nutrient leaves (Simulation 1, left panels) and high nitrogen leaves (Simulation 2 , right panels).

nitrogen, microbes became phosphorus limited except near the end of the simulation when nitrogen again became limiting (Fig. 3, lower panel). The leaf decay rate was identical to the first simulation $\left(\mathrm{k}=0.02 \mathrm{~d}^{-1}\right)$. Detrital $\mathrm{C}: \mathrm{N}$ was initially low because of the higher nitrogen content of the leaves, but towards the end of the 90 days it approached the same value as in the first simulation (Fig. 5, lower panels). Nitrogen uptake was lower (Fig. 6, lower panels) but nitrogen mineralization was about the same (Fig. 7, lower panels), though both began without the initial delay seen in the low leaf nitrogen simulation. As a result, there was greater net mineralization of nitrogen (Fig. 8, lower panels) and higher water column nitrogen concentration later in the simulation (Fig. 9, lower panels). Water column phosphorus concentration was initially lower than Simulation 1, but after about 15 days they were very similar (Fig. 9, upper panels), and export of dissolved and particulate phosphorus were essentially the same as in Simulation 1 (Fig. 10, upper panel, Table 2). Nitrogen concentration was not as low early but was higher than Simulation 1 later (Fig. 9, lower panels). As a result, the cumulative export of dissolved nitrogen exceeded export when there was no uptake or mineralization (Fig. 10, lower panel). 


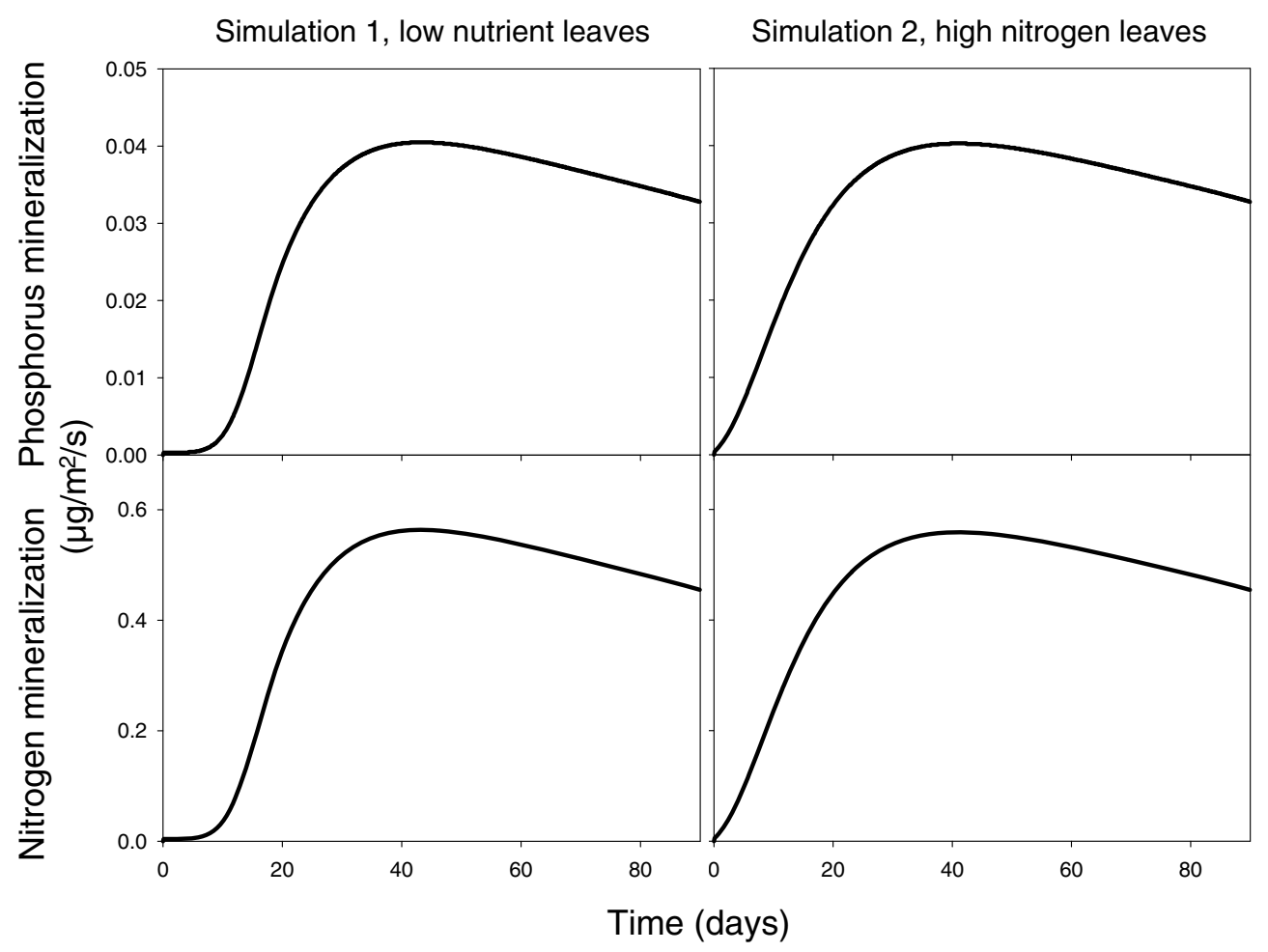

Figure 7. Phosphorus (upper panels) and nitrogen (lower panels) mineralization in decomposing leaves for simulations with low nutrient leaves (Simulation 1, left panels) and high nitrogen leaves (Simulation 2 , right panels). All mineralization was indirect.

\section{Discussion}

Model simulation studies necessarily reflect both the structure of the model and the data used to parameterize it. Some of the parameter values we used (Table 1), such as stream water nutrient concentrations, are well-measured values, but other parameters are not well known. The goal of this modeling project was not to produce a "valid" model. Instead, we hope that our results are interesting and useful in identifying critical uncertainties and research directions. Based on our results, we address the following questions:

Do microbial processes on decaying leaves modify water column nutrient concentrations? The results of our simulations show very large concentration changes, especially in the limiting nutrient. However, the magnitude of change in actual stream concentrations is probably much lower because leaf fall does not occur as a single pulse of uniform leaves. In deciduous forests of temperate areas of the world, leaf fall may be spread over several months and typically consists of a mixture of leaf species with different rates of conditioning and decay (e.g., Cummins et al., 1989; WeBster et al., 1999). Consequently, the effect of microbial uptake and mineralization in real streams should be much more subdued than we observed in these simulations. Research has shown that uptake of stream nutrients is related to leaf decay processes. Mulholland et al. (1985) demonstrated that phosphorus uptake 


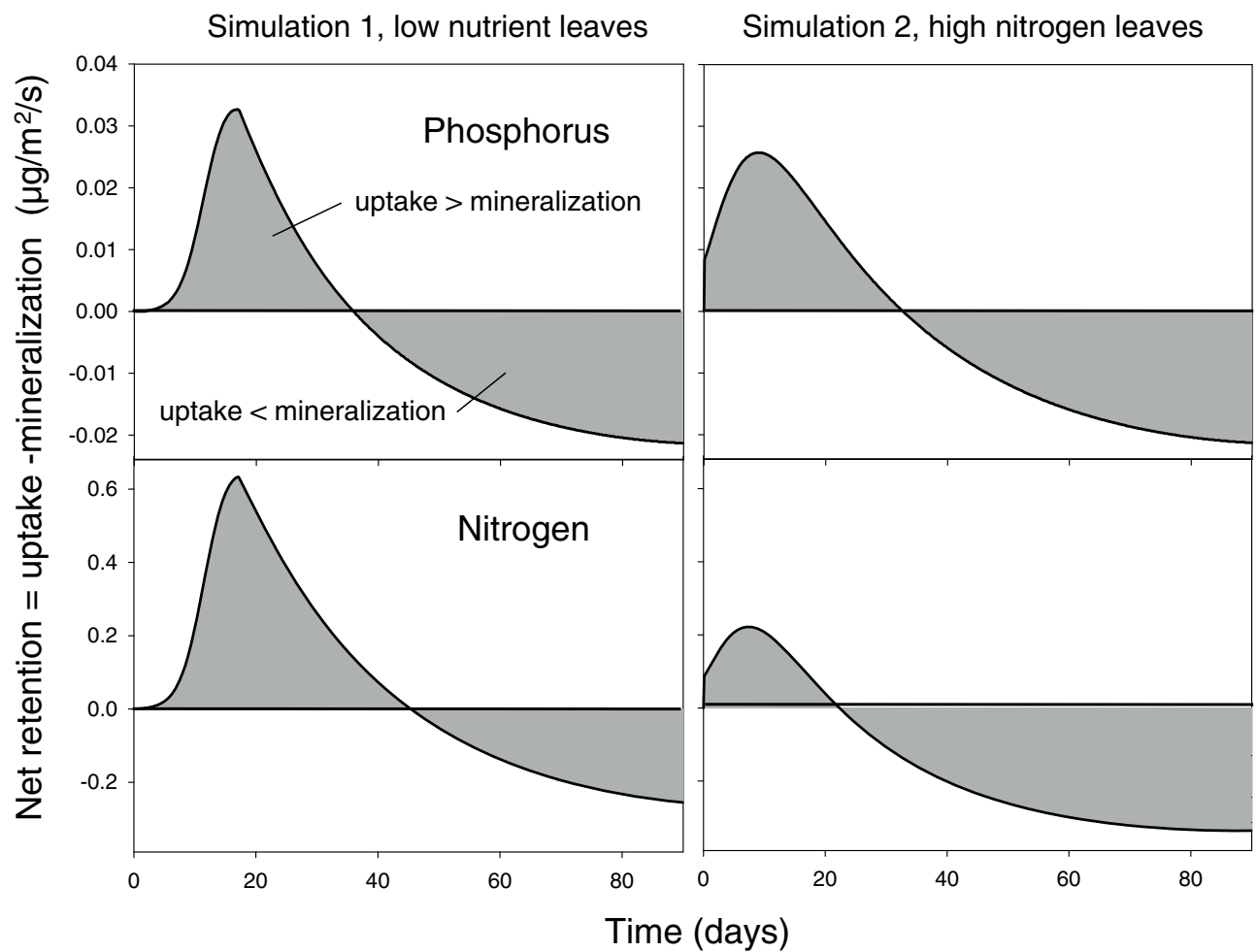

Figure 8. Net retention (= uptake - mineralization) of phosphorus (upper panels) and nitrogen (lower panels) for simulations with low nutrient leaves (Simulation 1, left panels) and high nitrogen leaves (Simulation 2, right panels). Points above the zero line represent times when uptake exceeded mineralization, and points below the line are times when mineralization exceeded uptake.

length was clearly correlated with the standing stock of benthic organic matter in Walker Branch, Tennessee, USA, and WeBster et al. (2001) found a similar result for ammonium and phosphate uptake in a small stream at Coweeta, North Carolina, USA. In another study of Walker Branch, Mulholland (2004) saw sharp declines in both nitrate and phosphate concentrations during and just after autumn leaf fall. Further, TANK et al. (2000) reported very rapid uptake of ammonium in another stream at Coweeta based on measurements made during peak leaf fall, and VALETT et al. (2008) found that nitrate uptake in streams draining deciduous forests was greatest when temperatures were low but leaf standing crop in the streams was high. While these and other studies (e.g., NewBold et al. 2006; HoEllein et al., 2007; GoODALE et al., 2009) provide strong evidence for the connection between nutrient uptake and decaying leaves, we know of no published evidence documenting elevation of water column nutrient concentrations resulting from decaying leaves. HOWARTH and FISHER (1976) found increases in water column nitrogen and phosphorus during leaf decay in laboratory chambers under elevated nutrient conditions, but we are not aware of similar results for natural streams.

Do microbes use both water column and substrate nutrients? There is substantial evidence that the microbes associated with leaf decay in streams do depend, at least to some extent, on water column nutrients. First, many studies have demonstrated that leaf decay 
Simulation 1, low nutrient leaves Simulation 2, high nitrogen leaves

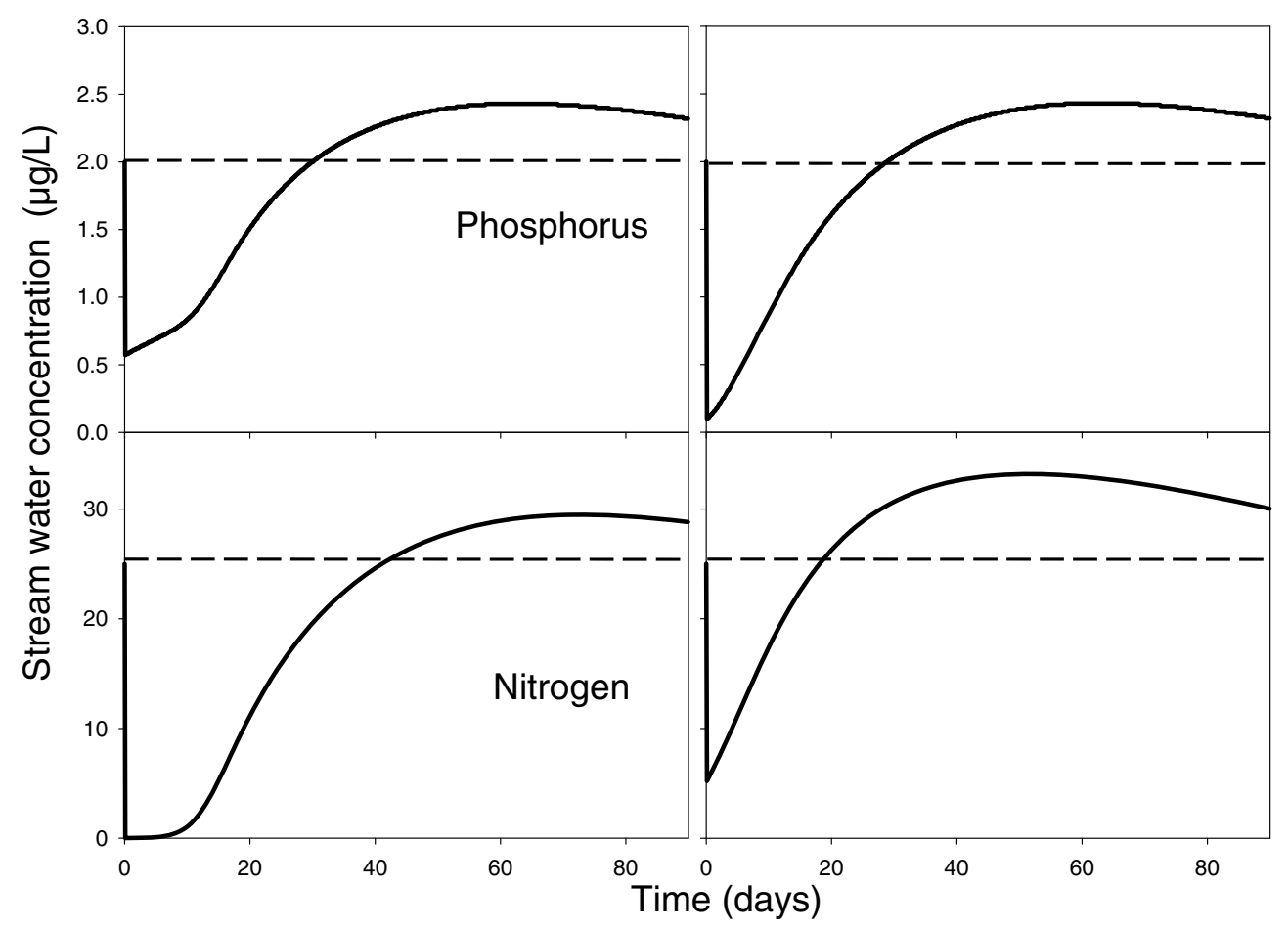

Figure 9. Stream water concentrations of inorganic phosphorus (upper panels) and nitrogen (lower panels) for simulations with low nutrient leaves (Simulation 1, left panels) and high nitrogen leaves (Simulation 2, right panels). The dashed lines represent the upstream and initial water nutrient concentrations.

and fungal activity are correlated with water column nutrient concentration (e.g., ELwOOD et al., 1981; Meyer and Johnson, 1983; Suberkropp and Chauvet, 1995; Gessner et al., 2007). Second, the studies described above showing the correlation between nutrient uptake and leaf standing crop rely on decline in water column concentrations to quantify uptake and are thus clear evidence that microbes are using these dissolved nutrients. Finally, direct experimentation has shown the use of water column nutrients. FindLAY and TENORE (1982) demonstrated that microbes growing on decaying Spartina grass acquired nitrogen primarily from the water. As a result, animals feeding on this detritus also met most of their nitrogen needs via microbial immobilization of water column sources.

A variety of stream experiments using radiolabeled phosphorus or ${ }^{15} \mathrm{~N}$ have shown rapid immobilization of water column nutrients (e.g., BALL and HoOPER, 1963; PETERSON et al., 1997), but the evidence for microbial use of substrate nutrients is less clear. For phagotrophs it seems obvious that the nutrients already in the organic matter would be accessed with greater energetic efficiency than immobilization of inorganic nutrients. However, for osmotrophs there may be no difference in efficiency between using nutrients already in the water or nutrients produced by their exoenzymes. The production of phosphatase enzymes under phosphorus limited conditions is clear evidence that microbes do use substrate phosphorus (e.g., KLOTZ, 1985). Also, the more rapid decomposition rates of low $\mathrm{C}: \mathrm{N}$ leaves 


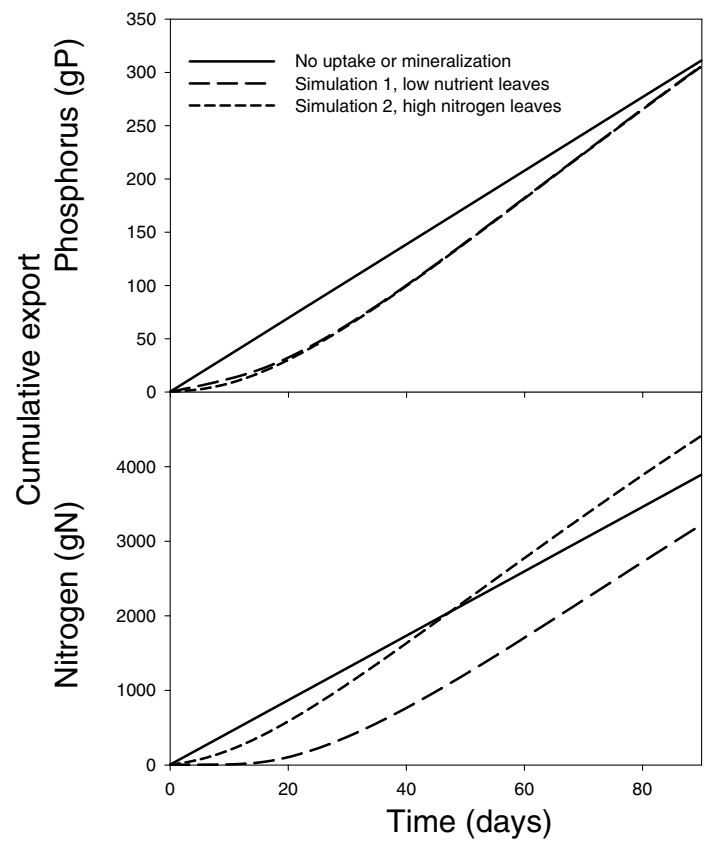

Figure 10. Cumulative export of dissolved inorganic phosphorus (upper panel) and nitrogen (lower panel) for simulations with low nutrient leaves (Simulation 1) and high nitrogen leaves (Simulation 2).

In each panel, the solid lines represent the cumulative export with no uptake or mineralization.

(e.g., KAUSHIK and HyNES, 1971) is indirect evidence that substrate nutrients are important. However, there is little direct evidence that extraction and use of these substrate nutrients actually occurs in headwater streams.

Is there a net retention or a net mineralization of nutrients in forested headwater streams? The model produced a small net mineralization of phosphorus within the $1000-\mathrm{m}$ reach in both simulations, net retention of nitrogen in Simulation 1, and net mineralization of nitrogen in Simulation 2 (Table 2). In Simulation 2, the retained nitrogen was exported as particulate organic nitrogen. In both simulations, the downstream export of dissolved inorganic nutrients was fairly similar to the upstream input of dissolved inorganic nutrients, despite the fact that substantial uptake and mineralization occurred within the reach. Except for the excess nitrogen in Simulation 2, most of the leaf nutrients were exported as organic particles.

If headwater streams are net retentive, the retained nutrients would eventually be exported as seston or dissolved organic matter and their mineralization would take place far downstream. Many studies have suggested that breakdown of leaves occurs near where they fall into streams (e.g., WeBSTER et al., 1999). However, leaf breakdown includes fragmentation, leaching, animal consumption, and decay. The organic carbon and nutrients in small particles and dissolved organic matter can be transported downstream a significant distance before they are ultimately mineralized (NEwBold et al., 2005). Based on data from 45 rivers, Cole and CARACO (2001) estimated that $50 \%$ of the organic carbon entering rivers is transported to the ocean. Thus streams may be net retentive of inorganic nutrients, transforming the nutrients in leaves and water to refractory dissolved organic matter and small particles. These materials are ultimately mineralized far downstream of where they entered the stream. Alternatively, the rapid uptake and subsequent mineralization of both substrate and immobilized nutrients may simply slow the downstream transport of inorganic nutrients to the ocean. 
Table 2. Input and export after 190 days.

\begin{tabular}{lrcc}
\hline Parameter & Input $^{1}$ & $\begin{array}{c}\text { Export for Simulation 1, } \\
\text { low nutrient leaves }\end{array}$ & $\begin{array}{c}\text { Export for Simulation 2, } \\
\text { high nitrogen leaves }\end{array}$ \\
\hline Dissolved inorganic phosphorus (g P) & 657 & 665 & 664 \\
Dissolved inorganic nitrogen (g N) & 8208 & 7710 & 8939 \\
Particulate organic phosphorus (g P) & 576 & 567 & 568 \\
Particulate organic nitrogen (g N) & & & \\
$\quad$ Simulation 1 & 6967 & 7469 & - \\
$\quad$ Simulation 2 & 9000 & - & 170 \\
Particulate organic carbon (kg C) & 216 & 171 & 8273 \\
\hline
\end{tabular}

${ }^{1}$ Dissolved inputs were calculated as upstream concentration $\times$ discharge $\times 190$ days. Particulate inputs were calculated as leaffall $\mathrm{x}$ total streambed area $\left(1000 \mathrm{~m}^{2}\right)$.

Does direct mineralization of substrate nutrients actually occur? As we have defined it, direct mineralization occurs when the nutrient content of organic matter is greater than the demand for nutrients by the microbes decomposing that material. Even with the high-nitrogen leaves in Simulation 2, we saw no direct mineralization of nitrogen because the C:N of the leaves (24) was greater than the $C: N$ of microbes (18). Are these realistic values? STERNER and ELSER (2002) reported a range of $C: N$ for leaves from 6 to 193 with a mean of 31 (converted from molar to mass). So our leaf nitrogen in Simulation 2 was somewhat higher than average, but certainly realistic for something like alder leaves. Their reported range of $\mathrm{C}: \mathrm{P}$ was 44 to 2300 with a mean of 375 , the value we used in both simulations. On the other hand, our carbon to nutrient ratios used for microbes $(\mathrm{C}: \mathrm{N}=18$ and $\mathrm{C}: \mathrm{P}=250)$ may be high. Reported values of fungal C:P range from 70 to 632 (BEEver and Burns, 1980; WALLANDER et al., 2002; OlsSON et al., 2008), though none of the data are for aquatic hyphomycetes. Bacteria probably have higher phosphorus content (lower $\mathrm{C}: \mathrm{P}$ ) than fungi (STERNER and ElSER, 2002, suggested $\mathrm{C}: \mathrm{P}<27$ for bacteria based on various reported studies), so a realistic $\mathrm{C}: \mathrm{P}$ for the assemblage of microbes on decaying leaves is probably lower than that of fungi and generally lower than that of decaying leaves. Fungal $\mathrm{C}: \mathrm{N}$ has been estimated from 4.5 to 22 (Newell and Statzell-TAllman, 1982; Findlay et al., 2002; Gulis et al., 2006). Again, adding bacteria to the mix would decrease the C:N (STERNER and ElSER, 2002, reported bacterial $\mathrm{C}: \mathrm{N}<6$ ). SANZONE et al. (2001) determined the $\mathrm{C}: \mathrm{N}$ of microbes on decaying leaves in streams at 7.0 for Ball Creek, North Carolina, 11.5 for Walker Branch, and 1.8 for Bear Brook, New Hampshire. Based on these data, we generally agree with Gulis et al. (2006), who stated that fungi have a lower C:N ratio than the substrate they feed on, but the possibility of direct mineralization certainly exists within the large ranges of reported carbon to nutrient ratios. Direct mineralization is unlikely to occur in streams where leaf fall is spread over time and is made up of a mix of leaf species, but it is possible where native vegetation has been replaced with a single tree species, especially if this species has nitrogen-fixing symbionts, such as black locust (Robinia pseudoacacia) and alder (Alnus spp.). Both of these species are natural successional species, but they have also been planted throughout the world.

Does microbial material constitute a substantial fraction of detritus? Our simulations suggest that this is possible (Fig. 2, lower panels). In our simulations, dead microbial tissue represented over $50 \%$ of the detrital material after 90 days; however, there is very little experimental evidence to support results of this magnitude. FINDLAY et al. (2002) found that living fungal biomass was insufficient to account for the increase in nitrogen content of 
decaying wetland litter, and they concluded that nitrogen sequestration in non-living microbial products or abiotic nitrogen retention must account for the high nitrogen content of the decaying litter. Several studies suggest that our model estimates of carbon and nitrogen accrual by living microbes may be fairly realistic (GESSNER and CHAUVET, 1994; SANZONE et al., 2001; Findlay et al., 2002; Gulis and Suberkropp, 2003; MethVIn and Suberkropp, 2003). For example, SANZONE et al. (2001) estimated that living microbes could account for as much as $22 \%$ of the detrital nitrogen in Walker Branch, Tennessee.

Our model and the simulations we report do not provide answers to our questions. Answers will only come from well-designed field and laboratory studies. Our hope is that these simulations will help identify promising directions for research that will improve our understanding of the complex relationship between leaf decay and nutrient dynamics in streams. We suggest four areas where additional research would be particularly illuminating. First, further estimates of nitrogen and especially phosphorus content of microbial assemblages in streams are essential for understanding of microbial demand for these nutrients. Second, there are very few measurements of Monod coefficients for nutrient uptake by heterotrophic microbes. The technique developed by PAYN et al. (2005) may be useful for such measurements. Third, we found no actual measurements of dead microbial tissue in decaying leaves in streams. There is a clear need to develop a technique for estimating the mass of dead microbial tissue associated with dead leaf tissue. Without this information, we don't really understand the dynamics of leaf decay. Finally, we need experimental information on what happens to the nutrients that were once part of the leaves before they fell in the stream. Our results suggest that they are mostly transported as organic particles and mineralized far downstream from where they entered the water.

\section{Acknowledgements}

Support for this research was provided by National Science Foundation grants DEB 98-15868 (NPARS) and DEB-02218001 (Coweeta LTER). Vlad Gulis, Kevin KuehN, and two anonymous reviewers provided valuable help in determining reasonable values for some of the model parameters. Beth CheEver and DAmon Ely provided helpful comments on the manuscript.

\section{References}

BALl, R. C. and F. F. Hooper, 1963: Translocation of phosphorus in a trout stream ecosystem. - In: Schultz, V. and A. W. J. Klement (eds.), Radioecology. Reinhold Publishing Corporation and The American Institute of Biological Sciences, Washington D. C., pp. 217-228.

BeEver, R. E. and D. J. W. BuRns, 1980: Phosphorus uptake, storage and utilization by fungi. - Adv. Bot. Res. 8: 127-219.

Cebrián, J., M. Williams, J. McClelland and I. Valiela, 1998: The dependence of heterotrophic consumption and accumulation on autotrophic nutrient content in ecosystems. - Ecol. Let. 1: 165-170.

Chauvet, E., 1987: Changes in the chemical composition of alder, poplar, and willow leaves during decomposition in a river. - Hydrobiologia 148: 35-44.

ChrZANowski, T. H. and M. KYle, 1996: Ratios of carbon, nitrogen and phosphorus in Psuedomonas fluorescens as a model for bacterial elemental ratios and nutrient regeneration. - Aquat. Microb. Ecol. 10: 115-122.

Cole, J. J. and N. F. CARAco, 2001: Carbon in catchments: Connecting terrestrial carbon losses with aquatic metabolism. - Mar. Freshw. Res. 52: 101-110.

Cromack, K. and B. A. CAldwell, 1992: The role of fungi in litter decomposition and nutrient cycling. - In: CARroll, G. C. and D. T. Wicklow (eds.), The Fungal Community, its Organization and Role in the Ecosystem. Marcel Decker, New York, pp. 601-618.

Cross, W. F., J. P. Benstead, P. C. Frost and S. A. Thomas, 2005: Ecological stoichiometry in freshwater benthic systems: Recent progress and perspectives. - Freshw. Biol. 50: 1895-1912. 
Cummins, K. W., M. A. Wilzbach, D. M. Gates, J. B. Perry and W. B. Taliaferro, 1989: Shredders and riparian vegetation. - BioScience 39: 24-30.

Dodds, W. K., E. Martí, J. L. Tank, J. Pontius, S. K. Hamilton, N. B. Grimm, W. B. Bowden, W. H. McDowell, B. J. Peterson, H. M. Valett, J. R. Webster and S. V. Gregory, 2004: Carbon and nitrogen stoichiometry and nitrogen cycling rates in streams. - Oecologia 140: 458-467.

Elwood, J. W., J. D. Newbold, A. F. Trimble and R. W. Stark, 1981: The limiting role of phosphorus in a woodland stream ecosystem: Effects of $\mathrm{P}$ enrichment on leaf decomposition and primary producers. - Ecology 62: 146-158.

Findlay, S. and K. TenoRE, 1982: Nitrogen source for detritivore: Detritus substrate versus associated microbes. - Science 218: 371-373.

Findlay, S. E. G., S. Dye and K. A. KueHN, 2002: Microbial growth and nitrogen retention in litter of Phragmites australis compared to Typha angustifolia. - Wetlands 22: 616-625.

Francoeur, S. N., 2001: Meta-analysis of lotic nutrient amendment experiments: Detecting and quantifying subtle responses. - J. N. Am. Benthol. Soc. 20: 358-368.

Frost, P. C., R. S. Stelzer, G. A. Lamberti and J. J. Elser, 2002: Ecological stoichiometry of trophic interactions in the benthos. - J. N. Am. Benthol. Soc. 21: 515-528.

GeSSNER, M. O. and E. CHAUVET, 1994: Importance of stream microfungi in controlling breakdown rates of leaf litter. - Ecology 75: 1807-1817.

Gessner, M. O., V. Gulis, K. A. Kuehn, E. Chauvet and K. Suberkropp, 2007: Fungal decomposers of plant litter in aquatic ecosystems. - In: KUBICK, C. P. and I. S. DruZHinina (eds.), Environmental and Microbial Relationships. Springer-Verlag, Berlin, pp. 301-325.

Golladay, S. W., J. R. Webster and E. F. Benfield, 1989: Changes in stream benthic organic matter following watershed disturbance. - Holarctic Ecol. 12: 96-105.

Goodale, C. L., S. A. Thomas, G. Fredriksen, E. M. Elliott, F. M. Flinn, T. J. Butler, and M. T. WALTER, 2009: Unusual seasonal patterns and inferred processes of nitrogen retention in forested headwater, of the Upper Susquehanna river. - Biogeochemistry 93: 197-218.

GuLIS, V. and K. SUBERKROPP, 2003: Leaf litter decomposition and microbial activity in nutrient-enriched and unaltered reaches of a headwater stream. - Freshw. Biol. 48: 123-134.

Gulis, V., K. Suberkropp and K. A. Kuehn, 2006: The role of fungi in carbon and nitrogen cycles in freshwater ecosystems. - In: GADD, G. M. (ed.), Fungi in Biogeochemical Cycles. Cambridge University Press, pp. 404-435.

Hoellein, T. J., J. L. Tank, E. J. Rosi-Marshall, S. A. Entrekin and G. A. Lamberti, 2007: Controls on spatial and temporal variation of nutrient uptake in three Michigan headwater streams. - Limnol. Oceanog. 52: 1964-1977.

Hood, J. M., M. J. VANNI and A. S. FleCKeR, 2005: Nutrient recycling by two phosphorus-rich grazing catfish: The potential for phosphorus-limitation of fish growth. - Oecologia 146: 247-257.

Howarth, R. W. and S. G. FisheR, 1976: Carbon, nitrogen, and phosphorus dynamics during leaf decay in nutrient enriched stream microecosystems. - Freshw. Biol. 6: 221-228.

HyNES, H. B. N., 1960: Biology of Polluted Waters. Liverpool University Press, Liverpool.

Jennings, D. H., 1995: The Physiology of Fungal Nutrition. Cambridge University Press, Cambridge.

Kaushik, N. K. and H. B. N. Hynes, 1971: The fate of the dead leaves that fall into streams. - Arch. Hydrobiol. 68: 465-515.

KLOTZ, R. L., 1985: Factors controlling phosphorus limitation in stream sediments - Limnol. Oceanog. 30: $543-553$.

Makino, W., J. B. Cotner, R. W. Sterner and J. J. Elser, 2003: Are bacteria more like animals than plants? Growth rate and resource dependence of bacterial C : N : P stoichiometry. - Funct. Ecol. 17: $121-130$.

Mcintyre, P. B., A. S. Flecker, M. J. Vanni, J. M. Hood, B. W. Taylor and S. A. Thomas, 2008: Fish distributions and nutrient cycling in streams: Can fish create biogeochemical hotspots. - Ecology 89: 2335-2346.

Methvin, B. R. and K. Suberkropp, 2003: Annual production of leaf-decaying fungi in two streams. J. N. Am. Benthol. Soc. 22: 554-564.

Meyer, J. L. and C. Johnson, 1983: The influence of elevated nitrate concentration on rate of leaf decomposition in a stream. - Freshw. Biol. 13: 177-183.

Mulholland, P. J., J. D. Newbold, J. W. Elwood, L. A. Ferren and J. R. Webster, 1985: Phosphorus spiralling in a woodland stream: Seasonal variations. - Ecology 66: 1012-1023. 
Mulholland, P. J., 2004: The importance of in-stream uptake for regulating stream concentrations and outputs of $\mathrm{N}$ and $\mathrm{P}$ from a forested watershed: Evidence from long-term chemistry records for Walker Branch watershed. - Biogeochemistry 70: 403-426.

Newbold, J. D., J. W. Elwood, R. V. O’Neill and A. L. Sheldon, 1983: Phosphorus dynamics in a woodland stream ecosystem: A study of nutrient spiralling. - Ecology 64: 1249-1265.

Newbold, J. D., S. A. Thomas, G. W. Minshall, C. E. Cushing and T. Georgian, 2005: Deposition, benthic residence, and resuspension of fine organic particles in a mountain stream. - Limnol. Oceanog. 50: $1571-1580$.

Newbold, J. D., T. L. Bott, L. A. Kaplan, C. L. Dow, J. K. Jackson, A. K. Aufdenkampe, L. A. Martin, D. J. VAn Horn and A. A. DE LOnG, 2006: Uptake of nutrients and organic C in streams in New York City drinking-water-supply watersheds. - J. N. Am. Benthol. Soc. 25: 998-1017.

Newell, S. Y. and A. Statzell-Tallman, 1982: Factors for conversion of fungal biovolume values to biomass, carbon and nitrogen: Variation with mycelial ages, growth-conditions, and strains of fungi from a salt-marsh. - Oikos 39: 261-268.

Olsson, P. A., E. C. Hammer, H. Wallander and J. Pallon, 2008: Phosphorus availability influences elemental uptake in the mycorrhizal fungus Glomus intraradices, as revealed by particle-induced X-ray emission analysis. - Appl. Environ. Microb. 74: 4144-4148.

Payn, R. A., J. R. Webster, P. J. Mulholland, H. M. Valett and W. K. Dodds, 2005: Estimation of stream nutrient uptake from nutrient addition experiments. - Limnol. Oceanogr. Methods 3: $174-182$.

Peters, G. T., J. R. Webster and E. F. Benfield, 1987: Microbial activity associated with seston in headwater streams: Effects of nitrogen, phosphorus and temperature. - Freshw. Biol. 18: 405-413.

Peterson, B. J., M. Bahr and G. W. Kling, 1997: A tracer investigation of nitrogen cycling in a pristine tundra river. - Can. J. Fish. Aquatic Sci. 54: 2361-2367.

Peterson, B. J., W. Wollheim, P. J. Mulholland, J. R. Webster, J. L. Meyer, J. L. Tank, E. Martí, W. B. Bowden, H. M. Valett, A. E. Hershey, W. B. McDowell, W. K. Dodds, S. K. Hamilton, S. Gregory and D. D. Morrall, 2001: Control of nitrogen export from watersheds by headwater streams. - Science 292: 86-90.

Sanzone, D. M., J. L. Tank, J. L. Meyer, P. J. Mulholland and S. E. G. Findlay, 2001: Microbial incorporation of nitrogen in stream detritus. - Hydrobiologia 464: 27-35.

Schade, J. D., J. F. Espeleta, C. A. Klausmeier, M. E. McGroddy, S. A. Thomas and L. X. Zhang, 2005: A conceptual framework for ecosystem stoichiometry: Balancing resource supply and demand. Oikos 109: 40-51.

Stelzer, R. S. and G. A. LAmberti, 2002: Ecological stoichiometry in running water: Periphyton chemical composition and snail growth. - Ecology 83: 1039-1051.

Sterner, R. W. and J. J. Elser, 2002: Ecological Stoichiometry. Princeton University Press, Princeton, New Jersey.

SubERKropp, K. and M. J. KLUG, 1976: Fungi and bacteria associated with leaves during processing in a woodland stream. - Ecology 57: 707-719.

Suberkropp, K. and E. Chauvet, 1995: Regulation of leaf breakdown by fungi in streams: Influences of water chemistry. - Ecology 76: 1433-1445.

Tank, J. L., J. L. Meyer, D. M. Sanzone, P. J. Mulholland, J. R. Webster, B. J. Peterson, W. M. Wollheim and N. E. LeONARD, 2000: Analysis of nitrogen cycling in a forest stream during autumn using a ${ }^{15} \mathrm{~N}$-tracer addition. - Limnol. Oceanog. 45: 1013-1029.

TANK, J. L. and W. K. DodDS, 2003: Nutrient limitation of epilithic and epixylic biofilms in ten North American streams. - Freshw. Biol. 48: 1031-1049.

TEZUKA, Y., 1990: Bacterial regeneration of ammonium and phosphate as affected by the carbon - nitrogen - phosphorus ratio of organic substrates. - Microbial Ecol. 19: 227-238.

TriskA, F. J. and B. M. BuCKLEY, 1978: Patterns of nitrogen uptake and loss in relation to litter disappearance and associated invertebrate biomass in six streams of the Pacific Northwest, USA. - Verh. Internat. Verein. Limnol. 20: 1324-1332.

Valett, H. M., S. A. Thomas, P. J. Mulholland, J. R. Webster, C. N. Dahm, C. S. Fellows, C. L. Crenshaw and C. G. Peterson, 2008: Endogenous and exogenous control of ecosystem function: N cycling in headwater streams. - Ecology 89: 3515-3527.

VANNI, M., 2002: Nutrient cycling by animals in freshwater ecosystems. - Annu. Rev. Ecol. Syst. 33: $341-370$. 
Wallander, H., L. Johansson and J. PALlon, 2002: PIXE analysis to estimate the elemental composition of ectomycorrhizal rhizomorphs grown in contact with different minerals in forest soil. - FEMS Microbiol. Ecol. 32: 147-156.

Webster, J. R., E. F. Benfield, T. P. Ehrman, M. A. Schaeffer, J. L. Tank, J. J. Hutchens and D. J. D'ANGelo, 1999: What happens to allochthonous material that falls into streams? A synthesis of new and published information from Coweeta. - Freshw. Biol. 41: 687-705.

Webster, J. R., J. L. Tank, J. B. Wallace, J. L. Meyer, S. L. Eggert, T. P. Ehrman, B. R. Ward, B. L. Bennett, P. F. Wagner and M. E. McTammany, 2001: Effects of litter exclusion and wood removal on phosphorus and nitrogen retention in a forest stream. - Verh. Internat. Verein. Limnol. 27: $1337-1340$.

Manuscript received October 13th, 2008; accepted January 16th, 2009 